\title{
PENGARUH KOMPOSISI WARNA PADA RUANG KERJA TERHADAP STRES KERJA
}

\author{
Rahmawan Dwi Prasetya* \\ Program Studi Desain Interior, Fakultas Seni Rupa, Institut Seni Indonesia Yogyakarta
}

This study is the result of an investigation of the influence of physical work environment toward stress at work place, particularly the color composition used. The research subjects were thirty students of ASMI (Secretary and Management Academy) who were divided into three groups, namely the Harmonious group, The Disharmonious group, and the Controlled group. The Work Stress Scale was used in the measurement process. The measurement was done three times: before the experiment, in the middle of the experiment (first 2 hours), and after the experiment (last 2 hours). The result was analysed using the Analysis of Variance (ANAVA) A-Mix-B model of SPS-2000 software application. The result of this study illustrated that there was a significant difference on work stress level impacted by color composition applied at work space $(F=4.149, p=0.026)$. The graphic of work stress average of the Harmonious group showed that Harmonious color composition did not affect the work stress significantly $(t=$ $0.520, p=0.306$ ). The dominantly white color composition that played a role as the Controlled group was in fact able to reduce the work stress. The graphic showed that the Controlled group tended to decrease significantly with these values $t=1.825, p=0.035$, and the initial work stress average was (0.000) higher than the final one (-22.800). The Disharmonious group showed that the color composition increased the work stress level $(t=3.177, p=0.001)$. It was concluded that Harmonious color composition at work space did not influence the work stress level, dominantly white color composition could reduce the work stress level, and inharmonious (Disharmonious) color composition application had chances to elevate the work stress level.

Keywords : color composition, work space, work stress

Dalam sebuah seminar bertema "Design and Color Trend 2005" di Yogyakarta, 2 Pebruari 2005, Naning Adiwoso, seorang desainer interior terkemuka di Indonesia, mengemukakan bahwa untuk mengimbangi kecepatan bekerja dalam berbagai perubahan yang begitu cepat dan dinamis diperlukan lingkungan kerja yang memberikan dukungan psikologis bagi pekerja dalam melaksanakan tugastugasnya, yang menjauhkannya dari dampakdampak negatif seperti kelelahan, penyakit, dan stres. Di samping itu secara eksplisit peranan warna ruang kerja menjadi sangat menentukan.

Pada sisi yang lain, merambahnya aliran Posmodern ke dalam bidang industri khususnya menarik pula untuk dicermati apabila dikaitkan dengan warna. Desain Posmodern selalu mencoba menghadirkan keberagaman warna (polychromy), ornamentasi, metafora, simbolisme, dan aneka ragam konvensi (Fuller, dalam Sumartono, 2004). Secara ekstrim bahkan dikatakan bahwa gaya desain Posmodern ini memberikan peluang kepada perancang untuk mencampuradukkan apa saja yang berbeda dan dari mana saja apa yang berbeda itu berasal (Sumartono, 2004). Dewasa ini gaya Posmodern semakin banyak diaplikasikan pada penataan ruang-ruang interior baik bangunan pribadi maupun bangunan publik, seperti pertokoan, industri, perkantoran, dan sebagainya. Sekalipun demikian, dampak psikologis yang timbul dari

*Korespondensi penulis dialamatkan ke Program Studi Desain Interior, Fakultas Seni Rupa, Institut Seni Indonesia Yogyakarta, Tel/Fax: +62 274417219 e-mail: deprazz@isi.ac.id 
rancangan beraliran Posmodern tersebut, khususnya komposisi warna yang diterapkan pada ruang kerja, menjadi pertanyaan yang menarik untuk dicermati. Apalagi jika dikaitkan dengan produktivitas dan kinerja individu yang beraktivitas di dalamnya.

Tulisan ini adalah ringkasan dari sebuah penelitian yang mencoba mengkaitkan antara penerapan komposisi warna pada ruang kerja dengan stres kerja. Pertanyaan yang kemudian muncul adalah apakah komposisi warna yang diterapkan pada ruang kerja mempengaruhi stres kerja? Jika ya, apakah komposisi warna harmonis dapat mengurangi stres kerja yang muncul dan apakah komposisi warna disharmonis dapat meningkatkan stres kerja? Tujuan penelitian adalah untuk mendapatkan bukti secara empiris yang menyatakan adatidaknya pengaruh komposisi warna ruang kerja terhadap stres kerja, dan bukti empiris yang menyatakan bahwa komposisi warna harmonis dapat mengurangi stres kerja, dan sebaliknya komposisi warna disharmonis dapat meningkatkan stres kerja.

Hasil penelitian diharapkan dapat menambah khasanah kajian bidang ilmu desain interior terutama yang berkaitan dengan interior kantor dan ruang kerja pada umumnya dan diharapkan penelitian ini juga dapat menjadi sumber bacaan untuk penelitian lain yang relevan. Selain itu, hasil penelitian ini diharapkan dapat menumbuhkan kesadaran bahwa mengikuti trend yang sedang berkembang memang penting untuk menunjukkan bahwa desain yang diciptakan selalu up to date, namun kehadiran suasana nyaman yang dicapai melalui komposisi warna pada ruang kerja merupakan salah satu pertimbangan penting untuk meningkatkan kinerja.

Ruang kerja di dalam bangunan sebuah kantor memiliki spesifikasi khusus pada fungsinya, yaitu untuk aktivitas bekerja. Dalam konteks ini, ruang kerja merupakan bagian dari lingkungan kerja yang bersifat fisik. Sukmana (2003) menegaskan bahwa lingkungan kerja fisik lebih banyak berhubungan dengan Psikologi Kerekayasaan, di mana kondisi fisik ruang kerja diharapkan dapat menciptakan kenyamanan bekerja bagi karyawan. Ini sangat berbeda dengan lingkungan kerja non-fisik yang lebih berorientasi pada interaksi sosial dan dinamika psikologi pekerja. Dengan kata lain kondisi fisik sebaiknya dibuat sedemikian rupa sehingga kondisi fisik di lingkungan kerja dapat meningkatkan produktivitas kerja karyawan. Munandar (2001) menjelaskan bahwa kondisi-kondisi fisik di lingkungan kerja yang dapat mempengaruhi kepuasan dan kenyamanan kerja adalah: (1) Rancangan ruang kerja (workspace design). (2) Rancangan pekerjaan (termasuk: peralatan kerja dan prosedur kerja). (3) Sistem penerangan (lighting). (4) Sistem ventilasi. (5) Tingkat "visual privacy" serta "acoustical privacy".

Pada rancangan ruang kerja, unsur warna, sebagai sifat dasar yang dimiliki oleh semua bentuk, memegang peranan yang sangat penting dalam hubungannya dengan aktivitas dalam ruang kerja tersebut. Riset telah membuktikan adanya reaksi tubuh manusia terhadap warna baik secara psikologis maupun fisiologis (Allen dan Stimpson, 1994). Riset tersebut membuktikan bahwa warna mempengaruhi suasana hati (mood) dan perasaan seseorang dalam hubungannya dengan space. Oleh karena itu, warna suatu ruang tertentu dapat dipilih sesuai dengan aktivitas yang dilakukan di dalam ruang tersebut. Warna mempengaruhi persepsi mata pada berat/bobot dan ukuran. Warna mempengaruhi persepsi seseorang pada suhu. Studi mengindikasikan bahwa suhu tubuh betul-betul naik-turun pada respon terhadap warna yang berbeda-beda. Sebagai contoh, merah, orange, dan kuning dapat meningkatkan suhu seseorang sekitar 5 sampai 7 derajat; warna dingin memiliki reaksi yang berlawanan. Warna juga dapat menyebabkan perasaan bosan dan ketenangan, atau stimulasi dan kelincahan. Warna menyebabkan sistem syaraf menjadi terangsang, dan tubuh bereaksi dengan cara yang negatif pada stimulus. Warna bahkan dapat mempengaruhi reaksi tubuh terhadap persepsi suara, rasa, bau badan, dan waktu.

Berdasarkan pertimbangan responrespon tubuh manusia terhadap warna tersebut, maka diperlukan kehati-hatian dalam memilih dan menggunakan warna pada ruang kerja. Meskipun demikian, warna tersebut tidak hanya berdiri sendiri. Warna 
dapat pula dilihat sebagai satu bagian dari sebuah komposisi warna apabila disusun bersama dengan warna-warna yang lain. Sehingga dengan demikian pengaruh warna tertentu terhadap tubuh manusia dapat diperlemah atau justru diperkuat dengan menyusunnya bersama-sama dengan warnawarna yang lain. Oleh karena itu pertimbangan penyusunan komposisi warna menjadi begitu penting.

Ruang kerja, seperti halnya ruangruang dalam bangunan yang lain, secara arsitektural mempunyai batas-batas fisik yang meliputi lantai, dinding, pintu, jendela, dan langit-langit (Ching, 1996: 14). Gilliat (2001:50) menyebut unsur-unsur ruang itu, dinding, lantai, dan jendela, sebagai major areas of color, yaitu bagian ruang yang memiliki area warna yang utama, yang mampu memberikan efek visual warna dominan bagi pemakai ruang itu.

Pengaturan komposisi warna merupakan pertimbangan utama dalam mengaplikasikan warna ke dalam ruang kerja. Komposisi warna ruang kerja merupakan penerapan warna dengan komposisi tertentu pada ruang kerja. Aplikasi warna tersebut meliputi semua unsur ruang (lantai, dinding, dan langit-langit).

\section{Komposisi Warna Harmonis}

Komposisi warna harmonis berarti paduan dua buah warna atau lebih, yang selaras sehingga membentuk paduan warna yang sempurna dan merupakan satu kesatuan, Komposisi warna harmonis dibuat berdasarkan skema warna yang mengacu pada lingkaran warna yang ditemukan oleh Sir David Brewster (Levenson, 1980) dan disempurnakan oleh Albert Munsell (Darmaprawira, 2002) yang kemudian disebut Sistem Munsell. Konsep ini menghasilkan beberapa komposisi warna harmonis, yaitu Monokromatik (monochromatic), Analog (analogous), dan beberapa komposisi Komplementer (direct complement, triad complement, split complement, alternate complement, dan tetrad) (Allen \& Stimpson, 1994; Ching, 1996; Levenson, 1980).

Komposisi warna analog adalah penyusunan beberapa warna yang seiring, di dalam Lingkaran Warna Munsell yang terletak berdekatan dan memiliki nilai kekuatan warnanya tidak jauh berbeda. Komposisi warna komplementer, atau disebut juga warna kontras merupakan perpaduan dua warna atau lebih yang memiliki posisi/letak yang berseberangan dalam Lingkaran Warna Munsell. Komposisi direct complement atau kontras langsung terdiri dari 2 warna yang berseberangan. Apabila satu warna dipertentangkan dengan dua warna disebelah warna komplemennya, susunan warna demikian disebut split complement atau kontras terpisah. Kontras ganda (double complement), adalah kombinasi warna yang terdiri dari dua warna yang dipertentangkan dengan dua warna diseberangnya. Ketiga kontras tersebut di atas adalah kontras yang merupakan 'adu kekuatan' warna, karena intensitasnya masing-masing sama. Kontras diantara warna-warna kuarsier tidak memiliki kekuatan yang tinggi, karena kemurniannya telah diperhalus melalui pencampuran.

Komposisi warna monokrom adalah komposisi warna yang paling sederhana. Jumlah warna yang terlibat hanya satu, namun dipadukan dengan campuran warna itu dengan warna netral putih atau hitam. Kombinasinya bisa saja terdiri dari merah, merah muda, merah pucat/pastel, maroon atau kombinasi warna biru, yang terdiri dari biru muda, biru tua, biru laut, dan biru pastel.

\section{Komposisi Warna Disharmonis}

Komposisi warna disharmonis dapat diartikan sebagai paduan dua warna atau lebih, yang tidak selaras sehingga membentuk paduan warna yang tidak sempurna dan tidak mempunyai satukesatuan (Lomelaars, 1968). Komposisi warna disharmonis merupakan komposisi yang disusun tidak dengan menggunakan skema warna yang didasarkan atas Lingkaran Warna Munsell. Ching (1996) berpendapat bahwa cocok atau tidaknya suatu warna dengan warna yang lain pada akhirnya tergantung pada bagaimana dan di mana warna tersebut digunakan, dan bagaimana warna tadi cocok dalam skema warna. Durret dan Trezone (1982, dalam Bridger, 1995) berpendapat bahwa komposisi warna yang sebaiknya dihindari dalam kaitannya dengan respon visual manusia adalah penggunaan pasangan warna dalam 
skema warna komplementer (direct complement, triad complement, split complement, alternate complement, dan tetrad) dan pengaturan komposisi yang menggunakan lebih dari 7 warna.

Kriteria komposisi warna harmonis dalam hal ini mengacu pada skema warna yang didasarkan atas Lingkaran Warna Munsell. Dalam eksperimen, komposisi warna harmonis menggunakan skema warna monokrom biru, dengan pertimbangan kesederhanaan dan kemudahan dalam aplikasinya. Skema warna monokrom adalah skema yang efektif dan paling sering digunakan pada ruang-ruang interior bangunan publik. Warna tunggal dapat memberi variasi diantara gradasi warna, dari warna terang sampai yang tergelap, dan dari intensitas tinggi sampai ke netral. Masingmasing warna dengan ragamnya menciptakan cita rasa kesatuan dan keselarasan. Penerapan skema warna monokromatik adalah cara yang paling aman dan efektif (Levenson, 1980).

Warna biru dipilih sebagai warna monokrom dengan pertimbangan yang didasarkan atas hasil studi Fisher (2005) yang mengungkapkan bahwa warna abu-abu kebiruan merupakan satu-satunya warna tanpa "after image" yang tertinggal di otak kita, abu-abu muda kebiruan menghasilkan latar belakang yang besar untuk keseriusan berfikir. Secara keseluruhan efisiensi dapat ditingkatkan dengan menggunakan warna biru langit dan biru laut. Dalam eksperimen, komposisi warna disharmonis mempergunakan 8 jenis warna yang diaplikasikan pada dinding, lantai, dan window treatment seperti halnya pada komposisi monokrom.

\section{Stres Kerja}

Stres adalah tanggapan atau reaksi fisiologis dan psikologis seseorang terhadap stressor. Reaksi ini muncul sebagai akibat adanya kebutuhan-kebutuhan yang ingin dipenuhi baik yang berhubungan dengan lingkungan maupun tujuan-tujuan pribadi (Selye dalam Berry, 1998). Pengalaman stres dimulai pada saat seseorang berhadapan dengan stresor dan berusaha untuk bertahan. Pertahanan diri yang melemah karena stresor yang datang terus menerus mengakibatkan munculnya gejala-gejala stres pada orang itu. Stres kerja adalah stres yang muncul di lingkungan pekerjaan. Stres kerja yang berkepanjangan menimbulkan gangguan kesehatan fisik dan psikologis. Sebagai contoh, stres dapat mengakibatkan timbulnya penyakit fisik, perilaku psikotik, dan burnout (Berry, 1998). Burnout, istilah yang sering muncul dalam pembicaraan mengenai stres kerja, adalah sebuah pola yang teridentifikasi pada perilaku dari seseorang yang terindikasi melalui munculnya kelelahan yang ekstrim. Ketegangan (strain) adalah suatu akibat dari stres yang sering didiskusikan pada beberapa penelitian tentang stres kerja. Ketegangan dapat berupa tanda-tanda kesehatan fisiologis, psikologis, dan perilaku yang buruk.

Stres kerja banyak dipengaruhi oleh lingkungan kerja yang tidak nyaman (Evan \& Johnson, 2000). Ini sejalan dengan Berry (1998) yang menyebutkan bahwa stresor lingkungan lebih mudah mempengaruhi seseorang dari pada stresor yang lain. Sekalipun demikian, lingkungan menjadi stresor tergantung pada bagaimana seseorang menanggapi lingkungannya. Lingkungan kerja itu sendiri adalah lingkungan yang berada di sekitar pekerja, yang terbagi menjadi dua, yaitu lingkungan fisik dan lingkungan non-fisik. Ruang kerja merupakan bagian dari lingkungan kerja fisik yang melingkupi karyawan dalam melakukan pekerjaannya. Beberapa aspek lain seperti peralatan, pencahayaan, penghawaan, akustikal, tata letak perabot juga termasuk dalam lingkungan kerja fisik (Berry, 1998). Sedangkan lingkungan kerja yang bersifat non-fisik, tidak saja berkaitan dengan aspek psikologis, namun juga aspek sosial.

Munculnya stres kerja dapat ditengarai melalui beberapa indikator, yaitu dengan mengukur tekanan darah, pernafasan, denyut nadi, galvanic skin response, aktivitas fokal, aktivitas elektrik otak, kadar glukosa dalam darah, dan kadar epinephrine dan norepinephrine dalam urine (Selye dalam Berry, 1998; Brunning \& Frew, 1987). Pengukuran stres juga dilakukan dengan Skala Stres Kerja dengan menggunakan 7 faktor yang mengindikasikan tingkatan stres yang dirasakan, meliputi gangguan, kecemasan, tidak-santai (unrelax), keputusasaan, kesedihan, ketidakpuasan, 
dan ketegangan (Evan \& Johnson, 2000)

Stres kerja banyak dibicarakan dalam berbagai penelitian sebagai faktor yang memiliki pengaruh yang kuat terhadap kinerja karyawan. Stres kerja yang terjadi secara terus menerus dalam waktu yang panjang menimbulkan gangguan psikologis seperti perilaku psikotik, dan burnout (Berry, 1998). Stres kerja dapat pula menyebabkan timbulnya gangguan-gangguan pada fisik yang berimplikasi pada masalah kesehatan seperti timbulnya penyakit lambung, paruparu, jantung, tekanan darah tinggi, dan sebagainya. Karyawan yang mengalami stres kerja yang berkepanjangan berpotensi mengalami gangguan-gangguan kesehatan tersebut. Akibatnya produktifitas dan kinerjanya akan menurun drastis dan terlepas dari posisinya dalam organisasi, hal itu akan mempengaruhi kinerja organisasi secara keseluruhan, langsung maupun tidak langsung.

Beberapa stresor memiliki peluang yang hampir setara dalam mempengaruhi timbulnya stres. Bahkan kadang-kadang stresor tersebut muncul bersamaan, tidak satu demi satu. Kondisi mental yang rapuh akan semakin mempercepat timbulnya stres. Beban kerja yang berat, baik dari segi kualitas maupun kuantitas, dapat menimbulkan perasaan putus asa dan rasa cemas. Ini adalah sebagian indikasi timbulnya stres kerja. Konflik peran dan hubungan yang tidak harmonis antar karyawan juga dapat menimbulkan stres kerja.

Lingkungan kerja yang bersifat fisik seringkali juga dituding sebagai penyebab timbulnya stres kerja. Lingkungan kerja fisik dapat direspon secara langsung oleh karyawan melalui alat inderanya. Suara bising, temperatur panas, kurangnya pencahayaan, atau sempitnya area bekerja, berpotensi menimbulkan stres kerja. Unsur ruang kerja sebagai bagian dari lingkungan kerja, yang meliputi lantai, dinding, dan langitlangit beserta aksesorisnya memiliki pengaruh yang besar terhadap stres yang dirasakan oleh karyawan pengguna ruang. Oleh karena itu, perancangan ruang kerja semestinya mempertimbangkan aspek psikologis karyawan penggunanya disamping aspek-aspek yang bersifat fisiologis. Warna sebagai salah satu aspek dalam perancangan ruang kerja seharusnya juga dipertimbangkan penerapannya sebab riset telah membuktikan adanya reaksi tubuh manusia terhadap warna baik secara psikologis maupun fisiologis (Allen dan Stimpson, 1994).

Berdasarkan uraian di atas, maka hipotesis yang diajukan adalah bahwa ada perbedaan tingkat stres kerja ditinjau dari penerapan komposisi warna pada ruang kerja, penggunaan warna pada ruang kerja dengan komposisi yang harmonis mengurangi stres kerja, sedangkan penggunaan warna ruang kerja dengan komposisi yang tidak harmonis (disharmonis) menyebabkan peningkatan stres kerja.

\section{BAHAN DAN METODE}

Variabel dalam penelitian ini terdiri dari Stres Kerja sebagai variabel terikat serta Komposisi warna Harmonis dan komposisi warna Disharmonis sebagai variabel bebas. Tingkat stres kerja diukur dengan Skala Stres Kerja yang terdiri dari 7 dimensi stres, yaitu gangguan, kecemasan, tidak-santai, keputusasaan, kesedihan, ketidakpuasan, dan ketegangan (Evan \& Johnson, 2000). Dimensi-dimensi stres kerja yang dikemukakan Evan dan Johnson (2000) disusun dan dikembangkan dalam bentuk skala perbedaan semantik (semantic differential scale). Dua kutub ekstrim yang digunakan adalah Sangat Tidak Sesuai (STS) dan Sangat Sesuai (SS) dengan sebelas pilihan jawaban (standard eleven score), yaitu antara 0 10. Semakin tinggi skor skala stres kerja, semakin tinggi tingkat stres yang dirasakan subjek. Pengukuran stres kerja dilakukan 3 kali selama pelaksanaan eksperimen berlangsung, yaitu sebelum sesi eksperimen, ditengah sesi eksperimen ( 2 jam pertama), dan di akhir eksperimen (2 jam terakhir).

Eksperimen diselenggarakan di kampus Program Studi Desain Interior Institut Seni Indonesia (ISI) Yogyakarta, dalam ruang yang berukuran $9 \times 9$ meter. Kondisi aklimatisasi dan pencahayaan setiap ruang untuk 3 kondisi eksperimen tersebut dikontrol secara cermat dengan menggunakan alatalat Anemometer, Luxmeter/Lightmeter, dan Sound-levelmeter. Ketiga kondisi perlakuan 
berada dalam level yang sama, baik suhu $\left(26,7^{\circ} \mathrm{C}\right)$, kebisingan suara $(54,8 \mathrm{~dB})$ maupun kuat pencahayaan (502 lux).

Subjek yang diikutsertakan dalam eksperimen ini berjumlah 30 orang mahasiswi Akademi Sekretari dan Manajemen (ASMI) jurusan sekretari. Pemilihan subjek yang berasal dari ASMI jurusan sekretari ini dilakukan dengan pertimbangan bahwa tugas seorang sekretaris adalah berhubungan dengan surat-menyurat dan diasumsikan setiap subjek mampu mengoperasikan program Microsoft Word (tugas eksperimen)

Subjek diberi honor sebagai kompensasi atas keikutsertaannya. Seluruh subjek dinyatakan berada dalam kondisi normal penglihatannya melalui test buta warna yang dilakukan sebelum eksperimen berlangsung. Ada dua alasan mengapa subjek yang diambil berjenis kelamin wanita. Pertama, sebagian besar karyawan yang bertugas pada bagian administrasi dan kesekretariatan adalah wanita. Yang kedua, menurut Stoney, dkk (Evans \& Johnson, 2000) ditemukan perbedaan gender dalam respon psikologis terhadap stresor. subjek yang berjumlah 30 orang tersebut dibagi dalam 2 kelompok perlakuan dan 1 kelompok kontrol, masing-masing berjumlah 10 orang.

Pada kondisi perlakuan 1, warna ruang kerja dengan komposisi Harmonis, digunakan komposisi warna Monokrom dengan satu warna primer dalam skema warna yang mengacu pada Lingkaran Warna Sistem Munsell, yaitu biru. Pada ruang yang lain (kondisi perlakuan 2, yaitu warna ruang kerja dengan komposisi Disharmonis) digunakan warna merah yang dikombinasikan dengan warna hijau, biru, kuning, jingga, coklat, ungu, dan krem, yang disusun secara acak pada dinding, lantai, jendela, dan pintu. Pada kondisi kontrol, komposisi warna ruang kerja yang didominasi warna putih diaplikasikan pada ruang yang lain.

Sebelum eksperimen dimulai, subjek diminta untuk mengisi kuesioner yang telah disediakan. Hasil pengukuran ini digunakan sebagai data pre-test (amatan awal). Seluruh subjek kemudian diminta untuk menyalin tulisan dengan program Microsoft Word pada komputer yang telah disediakan dari artikel yang isinya tidak ada hubungannya dengan eksperimen ini sama sekali (tentang kedirgantaraan). Selanjutnya, subjek diminta untuk bekerja dengan santai, seperti kebiasaan mereka bekerja, dan secara eksplisit diberitahu bahwa tidak ada yang mengawasi selama mereka bekerja. Hal ini dilakukan untuk menghindari dampak yang ditimbulkan oleh pengawasan atau monitoring terhadap kinerja karyawan (Larson \& Callahan, 1990), sehingga dikhawatirkan akan mempengaruhi hasil eksperimen ini. Pada akhir 2 jam pertama, subjek diminta mengisi kuesioner untuk mengukur tingkat stres yang dialaminya. Pengukuran ini digunakan sebagai middletest (amatan antara). Setelah pengukuran kedua, subjek diminta melanjutkan tugas menyalinnya.

Dua jam kemudian, setelah sesi eksperimen berakhir, subjek diminta untuk mengisi kuesioner lagi sebagai post-test (amatan akhir) Pengukuran stres kerja yang dilakukan 3 kali selama berlangsungnya eksperimen bertujuan untuk memastikan bahwa pengukuran tersebut mencerminkan aktivitas hanya selama periode eksperimen. Data hasil pengukuran dianalisis menggunakan teknik Analisis Variansi dengan bantuan SPS-2000 modul ANAVA AMx-B edisi Sutrisno Hadi (Hadi \& Pamardiningsih, 2000).

\section{HASIL DAN PEMBAHASAN}

Hipotesis yang diajukan, yaitu ada perbedaan tingkat stres kerja ditinjau dari penerapan komposisi warna pada ruang kerja, penerapan komposisi warna Harmonis mengurangi stres kerja, penerapan komposisi warna Disharmoni meningkatkan stres kerja diuji dengan teknik analisis variansi AGabung-B (ANAVA 1-Jalur Gabung 1-Faktor).

Berdasarkan pengujian Uji-F yang dilakukan, diperoleh nilai $F=4.149, p=0.026$ (signifikan). Ini menunjukkan bahwa berdasarkan uji-F, hipotesis yang diajukan dinyatakan diterima, bahwa ada perbedaan stres kerja ditinjau dari penerapan komposisi warna ruang kerja.

Uji-t yang dilakukan terhadap stres kerja dalam kelompok Harmonis dengan stres kerja dalam kelompok Disharmonis menghasilkan nilai $t=1.818, p=0.039$ (signifikan). Rerata stres kerja pada kelompok 
Harmonis (-0.067) lebih kecil dari pada rerata stres kerja kelompok Disharmonis (21.500). Hasil Uji-t ini menunjukkan bahwa ada perbedaan yang signifikan pada tingkat stres kerja ditinjau dari komposisi warna ruang kerja, stres kerja pada kelompok Disharmonis lebih tinggi dari pada stres kerja pada kelompok Harmonis. Uji-t antara stres kerja dalam kelompok Disharmonis dengan stres kerja dalam kelompok Kontrol menunjukkan perolehan nilai $t=2.844, p=0.004$ (sangat signifikan). Selanjutnya rerata stres kerja dalam kelompok Disharmonis (21.000) lebih besar dari pada rerata stres kerja kerja dalam kelompok Kontrol (-12.233). ini berarti ada perbedaan yang signifikan antara stres kerja dalam kelompok Disharmonis dan stres kerja dalam kelompok Kontrol. Dengan demikian, melalui Uji-t tersebut dapat disimpulkan bahwa hipotesis diterima, ada perbedaan tingkat stres kerja ditinjau dari penerapan komposisi warna ruang kerja, komposisi warna Disharmonis meningkatkan stres kerja.

Uji-t antara stres kerja dalam kelompok Harmonis dengan stres kerja dalam kelompok Kontrol menunjukkan perolehan nilai $t=$ $0.518, p=0.158$ (nirsignifikan). Ini menunjukkan bahwa tidak ada perbedaan yang signifikan antara stres kerja dalam kelompok Harmonis dan stres kerja dalam kelompok Kontrol. Sekalipun demikian, pada 2 jam terakhir atau pengukuran terakhir, hasil Uji-t 2-jalan AB yang membandingkan antara stres kerja akhir pada kondisi Harmonis dengan stres kerja akhir pada kondisi Kontrol menunjukkan perolehan nilai $t=2.345, p=$ 0.011 (signifikan). Rerata stres kerja akhir pada kondisi Harmonis (6.500) lebih besar dari pada stres kerja akhir pada kondisi Kontrol (-22.800). Hal ini menunjukkan bahwa stres kerja akhir pada kondisi Harmonis lebih tinggi dari pada stres kerja akhir pada kondisi Kontrol. Dengan demikian hipotesis ditolak, bahwa walaupun ada perbedaan tingkat stres kerja ditinjau dari penerapan komposisi warna ruang kerja, tingkat stres kerja pada komposisi warna Harmonis ternyata justru lebih tinggi dari pada tingkat stres kerja pada komposisi warna Kontrol.

Hasil analisis data menunjukkan adanya perbedaan yang signifikan antara stres kerja pada kelompok Disharmonis dengan kelompok Kontrol. Perbedaan itu dinyatakan dengan lebih tingginya tingkat stres kerja kelompok Disharmonis dari pada tingkat stres kerja kelompok Kontrol ( $t=$ 2.844, $p<0.010)$. Rerata kelompok Disharmonis (21.000) lebih tinggi dari pada kelompok Kontrol (-12.233). Hasil ini menunjukkan bahwa komposisi warna Disharmonis pada ruang kerja mendukung peningkatan stres kerja orang yang beraktivitas di dalamnya.

Berbeda halnya dengan penggunaan komposisi warna Harmonis pada ruang kerja, yang dalam eksperimen menggunakan komposisi monokrom biru. Diluar dugaan, tingkat stres kerja pada kelompok Harmonis ternyata tidak berbeda secara signifikan dengan tingkat stres kerja pada kelompok Kontrol ( $t=1.026, p>0.050$, nirsignifikan). Ini berarti dapat dikatakan bahwa penggunaan komposisi warna Harmonis pada ruang kerja tidak ada bedanya dengan penggunaan komposisi warna yang digunakan dalam kelompok Kontrol, yakni dominan putih dalam kaitannya dengan stres kerja yang ditimbulkannya. Dugaan semula adalah bahwa komposisi warna Harmonis menurunkan tingkat stres kerja. Oleh karena itu, hipotesis yang menyatakan bahwa komposisi warna Harmonis pada ruang kerja mengurangi peningkatan stres kerja dengan demikian ditolak. Komposisi warna Harmonis pada ruang kerja tidak berpengaruh terhadap stres kerja.

Stres kerja pada kelompok Harmonis berbeda secara signifikan dengan stres kerja dalam kelompok Disharmonis $(t=1.818, p<$ $0.050)$, dengan rerata kelompok Harmonis (0.067) lebih rendah dari pada rerata kelompok Disharmonis (21.500). Artinya penerapan komposisi warna Harmonis memiliki pengaruh yang cenderung negatif terhadap stres kerja dari pada penerapan 
komposisi warna Disharmonis pada ruang kerja. Hal ini sejalan dengan hasil-hasil di atas. Jadi jika disederhanakan, hasil penelitian ini adalah

$\begin{array}{lll}\text { Disharmonis } & > & \text { Kontrol } \\ \text { Disharmonis } & > & \text { Harmonis } \\ \text { Harmonis } & = & \text { Kontrol }\end{array}$

Tidak adanya perbedaan yang signifikan antara Harmonis dan Kontrol, tampaknya menarik untuk dicermati. Ada kemungkinan bahwa komposisi warna monokrom yang diterapkan untuk kondisi Harmonis secara visual tampak serupa dengan kondisi Kontrol yang menggunakan dominasi putih pada ruang kerja, sehingga respon yang diperlihatkan oleh para subjek dari kedua kelompok tersebut menjadi relatif hampir sama.

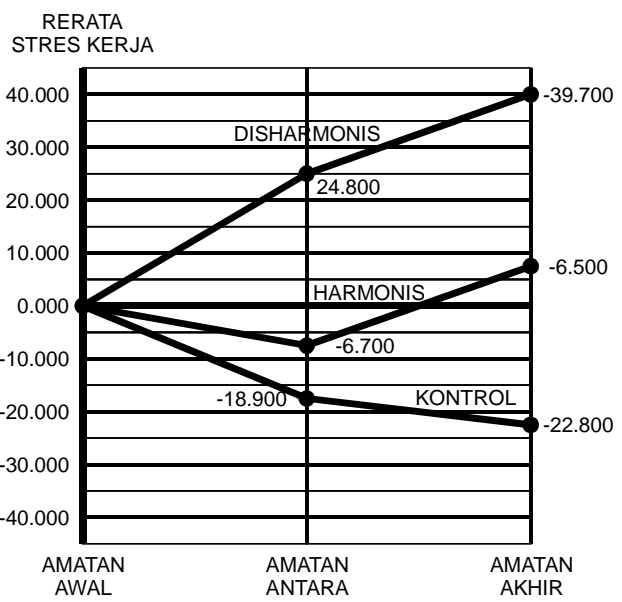

Gb.1. Grafik Rerata Stres Kerja

Sekalipun demikian, jika dikaitkan dengan waktu, maka terdapat perbedaan dengan hasil di atas. Pada 2 jam pertama, kondisi stres kerja pada kelompok Harmonis berbeda secara signifikan dengan kondisi stres kerja pada kelompok Disharmonis, namun tidak ada perbedaan yang signifikan dengan kelompok Kontrol (lihat grafik). Baru pada 2 jam kedua (setelah bekerja selama 4 jam) muncul perbedaan yang signifikan baik antara kondisi stres kerja kelompok Harmonis dengan kelompok Disharmonis maupun antara kelompok Harmonis dengan kelompok Kontrol.

Temuan ini dapat dijelaskan dengan teori Tsal dan Lavie (1993) yang menyatakan bahwa pada dasarnya orang lebih mudah memproses beberapa atribut (warna, bentuk, dan lokasi) dari suatu objek tunggal dari pada memproses atribut-atribut yang dimiliki oleh beberapa objek yang berbeda. Artinya, komposisi warna monokrom tentunya lebih mudah diproses sebab kehampirsamaan warna pada masing-masing objek menjadi tersamar, sehingga objek-objek tersebut menjadi tampak tunggal. Demikian pula, bahwa komposisi warna dominan putih pada kondisi Kontrol menjadi lebih mudah diproses dari pada komposisi warna monokrom. Kesulitan dalam memproses atribut-atribut tersebut menimbulkan gangguan bagi individu yang mengalaminya.

Gambar grafik menunjukkan bahwa pada 2 jam kedua (amatan akhir) terjadi perbedaan tingkat stres yang signifikan antara kondisi Harmonis dan Kontrol. Stres kerja pada kondisi Harmonis meningkat tajam setelah 4 jam subjek bekerja. Ini berarti teori Tsal dan Lavie (1993) tersebut berlaku setelah 4 jam bekerja dalam suatu ruangan. Hasil ini juga menunjukkan bahwa setelah 4 jam bekerja, komposisi warna ruang kerja yang didominasi warna putih, yang dalam hal ini berlaku sebagai kondisi Kontrol ternyata memiliki pengaruh negatif yang signifikan terhadap stres kerja. Komposisi warna putih ini mampu mengurangi stres kerja yang dialami oleh para subjek seperti yang terlihat pada gambar grafik.

Dari hasil analisis di atas dapat disimpulkan bahwa ada perbedaan tingkat stres kerja ditinjau dari komposisi warna ruang kerja. Adanya perbedaan itu memperlihatkan bahwa komposisi warna ruang kerja memiliki pengaruh yang signifikan terhadap pemunculan stres kerja. Komposisi warna Harmonis pada ruang kerja tidak mengurangi tetapi juga tidak meningkatkan stres kerja. Apabila dibandingkan dengan komposisi warna putih yang difungsikan sebagai Kontrol maka ada perbedaan yang cukup signifikan $(t=0.576, p>0.050$ pada 2 jam pertama, dan $t=1.173, p<0.050$ pada 2 jam terakhir). Rerata stres kerja akhir pada kondisi Harmonis (6.500) lebih besar daripada stres kerja akhir pada kondisi Kontrol (-22.800).

Berbeda halnya dengan stres kerja pada kondisi Kontrol yang memiliki 
kecenderungan menurun secara signifikan dengan $t=1.825, p<0.050$, rerata akhir (22.800) lebih rendah dari pada rerata awal (0.000).. Dengan demikian, apabila dikaitkan dengan pemunculan stres kerja, maka dapat disimpulkan bahwa penggunaan komposisi warna dengan dominasi putih pada ruang kerja lebih mampu menurunkan stres kerja dibandingkan dengan komposisi warna Harmonis monokrom. Komposisi warna dengan dominasi putih dapat mengurangi stres kerja. Berdasarkan hasil penelitian, dapat pula disimpulkan bahwa penggunaan komposisi warna yang tidak harmonis (Disharmonis) pada ruang kerja berpotensi meningkatkan stres kerja.

Beberapa saran yang didasarkan atas hasil penelitian adalah sebagai berikut:

1. Dalam perancangan suatu ruang kerja, aspek komposisi warna perlu dipertimbangkan secara lebih berhati-hati dengan tujuan untuk dapat semaksimal mungkin mereduksi tingkat stres kerja.

2. Penggunaan warna Disharmonis sebaiknya dihindari. Aliran Posmodern yang salah satunya bersifat dekonstruktif dan mencampuradukkan apa saja yang berbeda perlu untuk dihindari penerapannya dalam hal komposisi warna pada ruang kerja karena memiliki kecenderungan untuk mendukung peningkatan stres kerja.

3. Aplikasi komposisi warna Harmonis monokrom pada ruang kerja sebaiknya dilakukan secara berhati-hati, sekalipun komposisi warna Harmonis ini tidak memiliki pengaruh apapun terhadap pemunculan stres kerja.

4. Dominasi putih pada ruang kerja justru memiliki efek yang positif, yaitu memiliki kemampuan mereduksi peningkatan stres kerja dibandingkan dengan komposisi warna Harmonis dan Disharmonis. Berdasarkan hal itu, maka sebaiknya ruang kerja menggunakan komposisi warna yang didominasi putih agar dapat lebih mendukung kinerja.

5. Untuk penelitian selanjutnya, diperlukan replikasi eksperimen yang sejenis untuk lebih memantapkan teori yang dihasilkan. Terbuka juga kemungkinan untuk melakukan penelitian komposisi warna yang melibatkan warna lain dan pengaruhnya terhadap aspek-aspek perilaku dan kondisi psikologis manusia yang lain.

\section{UCAPAN TERIMAKASIH}

Penelitian ini didanai oleh dana Hibah Penellitian Proyek DUE-Like Batch IV tahun 2005 Program Studi Desain Interior Fakultas Seni Rupa, Institut Seni Indonesia Yogyakarta. Terima kasih kepada Prof.Drs.Sutrisno Hadi,MA, Drs. Sumartono, MA, Phd., CV.Mowilex, dan semua pihak yang membantu pelaksanaan penelitian ini.

\section{DAFTAR PUSTAKA}

Adiwoso, N. 2005. Color Forecast 2004-2005. Makalah dipresentasikan pada Seminar Design and Color Trend 2005, Pebruari 2005, Yogyakart

Allen, P.S. \& Stimpson, M.E.1994. Beginnings of Interior Environment. New Jersey: Macmillan College Publishing Company, Inc.

Berry, L. M.1998. Psychology at work: An Introduction to Industrial and Organizational Psychology. Boston: McGraw-Hill Book Co.

Bridger, R.S. 1995. Introduction to Ergonomics, Singapore: McGraw-Hill, Inc.

Bruning, N. S., \& Frew, D. R. 1987. Effects of Exercise, Relaxation, and Management Skills Training on Physiological Stress Indicators: A Field Experiment. Journal of Applied Psychology, 72, 515-521.

Ching, F. D. K. 1996. Ilustrasi Desain Interior. Jakarta: Penerbit Erlangga.

Darmaprawira, S. 2002. Warna dan Kreativitas Penggunaannya. Bandung: Penerbit ITB.

Evans, G. W., \& Johnson, D. 2000. Stres and Open-Office Noise. Journal of Applied Psychology, 85, 779-783. 
UNTAS

ISSN 1978-0702 | VOL.1 | EDISI 1 | 2007

Fisher, J.J. 2005. Design Psychology. California: Ted Blake Publisher

Gawron, V. 1982. Performance Effects of Noise Intensity, Psychologycal Set, and Task Type and Complexity. Human Factors, 24, 225-243

Gilliat, M. 2001. Interior Design Course. London: Conran-Octopus Limited.

Hadi, S. 2000. Seri Program Statistik-versi 2000. Yogyakarta:UGM

Larson, J.R., \& Callahan, C. 1990. Performance Monitoring: How It Affects Work Productivity. Journal of Applied Psychology, 75, 530-538.

Levenson, H. 1980. Creating An Interior. London: Prentice Hall International Inc.

Lomelaars, H.C.A 1968. Pengantar IImu Warna. Yogyakarta: Penerbit ASRI.

Munandar, A.S. 2001. Psikologi Industri. Jakarta: Pusat Penerbitan Universitas Terbuka.

Sukmana, O. 2003. Dasar-dasar Psikologi Lingkungan. Malang: Bayu Media.

Sumartono 2004. Merenungkan Kembali Gerakan Anti-Desain. Jurnal Seni Rupa dan Desain, 01, 37-43

Tsal, Y., \& Lavie, N. 1993. Location Dominance in Attending to Color and Shape. Journal of Experimental Psychology, 19, 131-139. 